\title{
FORMING RESISTANCE DETERMINATION OF STEEL
}

\author{
Alexandra Novakova, Milan Brozek \\ Czech University of Life Sciences Prague \\ novakovaa@tf.czu.cz, brozek@tf.czu.cz
}

\begin{abstract}
Knowledge of the steel forming resistance is very important at all methods of the steel forming. During teaching the subjects "Manufacturing Technology I" and "Basic of Manufacturing Technology" our students get acquainted theoretically (in lectures) and practically (in laboratory practice) with cold forming and with hot working. At practices they can get practically acquainted with chosen technologies of cold forming, namely with shearing, bending, drawing and stamping. In the field of hot working the practice "Experimental determination of forming resistance using the forging test" was prepared. From theory it is known that properties of metals and their alloys vary with their forming. The change of resistance against the irreversible deformation is extremely expressive. At high temperatures the majority of metals and alloys are of better plasticity - the forming resistance is lower than at normal temperature. Laboratory tests were carried out at very different forming temperatures $\left(20^{\circ} \mathrm{C}, 400{ }^{\circ} \mathrm{C}, 700{ }^{\circ} \mathrm{C}\right.$ and $\left.1000^{\circ} \mathrm{C}\right)$. Forming was made using the fall hammer own design, made in workshops at our department. In this paper the results of three selected steel forming resistance evaluation are published. Steel 1 is unalloyed constructional fine-grained low carbon steel, steel 2 is chromemolybdenum steel and steel 3 is high speed steel. Using the obtained results the new laboratory practice was prepared and successfully tested for our students.
\end{abstract}

Keywords: steel, hot working, forming resistance, forging, laboratory tests.

\section{Introduction}

The lectures of both subjects include all basic engineering technologies, namely foundry work, forming operations [1], welding [2], soldering and brazing [3], adhesive bonding [4;5], surface protection [6], plastics processing, engineering metrology and cutting operations [7; 8]. Lectures are completed by the themes carried out in practice, namely the technological process of casting products, non-destructive testing, technological tests, metal hot working, metal cold working, spot welding, bonding of metallic and nonmetallic materials, length and angle measuring, control of gearings and threads, measuring of cutting edge temperature at turning etc. For study the students have at disposal beside the own notes from lectures the mimeographed texts. Next sources for study are at disposal in electronic form in the university web [9].

Forming technology pertains to the basic processes of manufacturing technology. The mankind has used forming for a relatively long time. From history not only the arm production (e.g., knives, swords, sabers, rapiers, axes, coats-of-arms, armour sheets and other parts of armour), but also other products (e.g., bars, railings) are universally known. But at that time the producers knew neither the theory nor basis of working. They managed only with the own and their ancestors' experiences. The bases of the metal working theory were formed in the $2^{\text {nd }}$ half of the $19^{\text {th }}$ century. Since that time a lot of pieces of knowledge have been obtained and forming becomes an integral part of the manufacturing technology. By forming not only semi-products for further processing (e.g., sheets, bars, rolled sections) but factory-finished products (e.g., screws, nuts, washers, gear wheels, crankshafts, rails) are made, too. From the theoretical point of view forming can be classified according to temperature, temperature effect, amount of deformation etc. In practice the forming processes are classified according to the applied force. From this point of view we distinguish shearing, bending, drawing, extrusion, stamping, forging, rolling etc. [10-12].

Further we deal with the classification according to the temperature. From theory it is known that properties of metals and their alloys vary with their forming. The change of resistance against the irreversible deformation is extremely expressive. At high temperatures the majority of metals and alloys are of better plasticity - the forming resistance is lower than at normal temperature. Plastic deformation can be realized by two basic procedures:

- by cold forming, when the forming temperature is lower than the recrystallization temperature,

- by hot working, when the forming temperature is higher than the recrystallization temperature.

Both procedures are of advantages and disadvantages and are used in practice [13; 14]. 
During the teaching our students get acquainted theoretically (in lectures) and practically (in laboratory practice) with cold forming as well as with hot working. At practices of the subjects "Manufacturing Technology I" and "Basic of Manufacturing Technology" they can get practically acquainted with the chosen technologies of cold forming, namely with shearing, bending, drawing and stamping. In the field of hot working the practice "Experimental determination of forming resistance using the forging test" was prepared $[11 ; 15 ; 16]$.

\section{Materials and methods}

Forming tests make it possible to study a row of partial influences, e.g., the influence of the forming temperature, strain rate, strain energy, dimensions and the shape of the test samples and if need be of the forming plate roughness. With regard to the dedicated time for this practice $(90 \mathrm{~min}) \mathrm{a}$ simplification was necessary. Only the influence of the forming temperature was followed.

The test procedure is the following: Students receive from the teacher the test rolls of about 16 $\mathrm{mm}$ diameter and about $16 \mathrm{~mm}$ height, from each tested steel [17-19] four pieces. In our tests, three test specimens were used from each material and from each temperature. This allowed us to perform a statistical evaluation of the measured data (see Table 2.). Before the test the students measure using the digital caliper and enlist in test report the roll real diameter $d_{0}$ and height $h_{0}$. Then three of rolls are put in the ready for use electric furnaces and are left there for 30 minutes for warming up to the forming temperature $\left(400{ }^{\circ} \mathrm{C}, 700^{\circ} \mathrm{C}\right.$ and $\left.1000^{\circ} \mathrm{C}\right)$. With regard to the safety instructions this operation is carried out exclusively under the teacher's supervision. The work begins with the rolls forging at the temperature of $20^{\circ} \mathrm{C}$. Using the tongs the samples are put on the fall hammer bottom die placed on the anvil block (weight $m_{s}=240 \mathrm{~kg}$ ). Using the lever the safety pin is unfasted and the hammer head (weight $m=39.5 \mathrm{~kg}$ ) strikes the sample. The fall hammer design (Fig. 1) makes it possible to choose the falling height. In this case the height of $H=0.5 \mathrm{~m}$ was chosen.

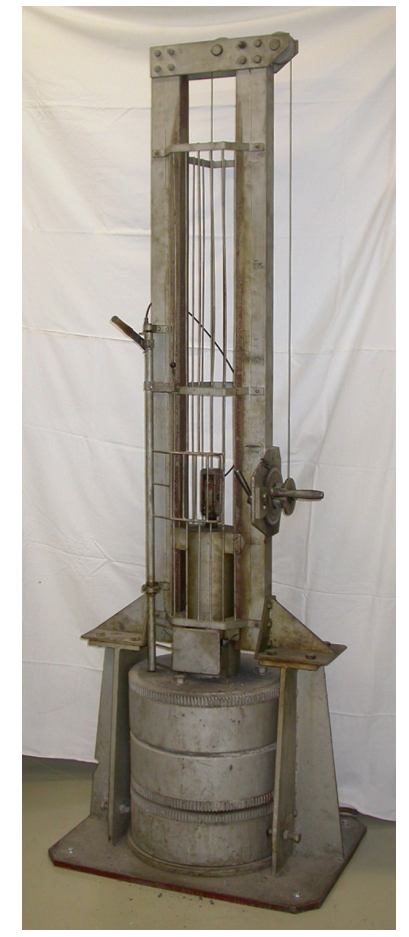

Fig. 1. Fall hammer [20]

Analogically the tests are carried out at higher temperatures. In this case the time between the samples taking out from the oven and their forming is very important. Because of the relatively quick sample cooling the oven temperatures are a little higher than the demanded forging temperatures. After forging of all rolls their height $h$ is measured. Then the data are computed [11].

The photos of the specimens before and after the test are shown in Fig. 2. Left is the sample before the test. Toward the right are the samples formed at the temperature $20^{\circ} \mathrm{C}, 400{ }^{\circ} \mathrm{C}, 700{ }^{\circ} \mathrm{C}$ and $1000{ }^{\circ} \mathrm{C}$. 


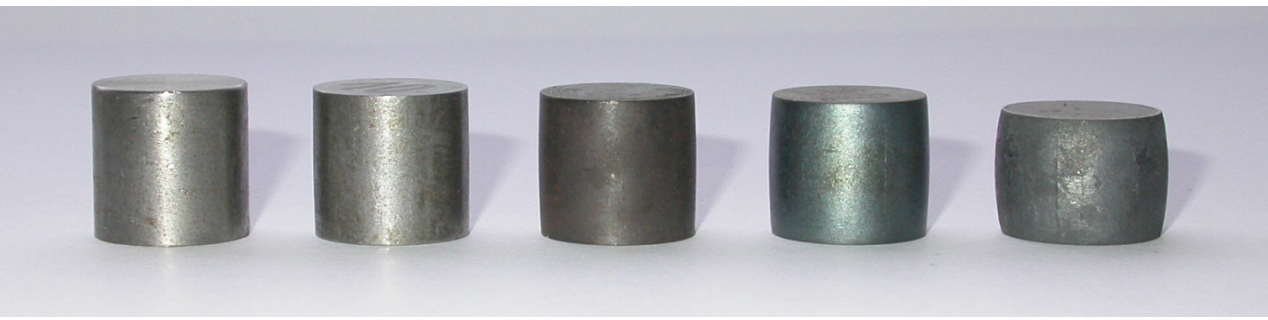

Fig. 2. Specimens before and after the test

The potential energy of the hammer head $A_{p}$ is computed using the equation (1)

$$
A_{p}=m \cdot g \cdot h=39 \cdot 5 \cdot g \cdot 0 \cdot 5=193.7 \mathrm{~J} .
$$

In the same way as with other mechanisms used in the field of the manufacturing technology the fall hammer is of some loss in energy. Therefore, at the test samples forming the whole above calculated energy is not exploited and this loss in energy must be taken in consideration. The efficiency of the fall hammer $\eta$ is calculated using the equation (2)

$$
\eta=\frac{m_{s}}{m+m_{s}}=\frac{240}{39.5+240}=0.86 .
$$

The deformation work of the hammer head $A_{d}$ is calculated using the equation (3)

$$
A_{d}=A_{p} \cdot \eta=193.7 .0 .86=166.3 \mathrm{~J} .
$$

For forming the resistance value for the test samples in form of the cylinder, made from different steels and formed at different temperatures, is calculated using the equation (4)

$$
k_{o}=\frac{A_{d}}{V_{o} \cdot \ln \frac{h_{0}}{h}} \mathrm{MPa},
$$

where $V_{o}=\frac{\pi \cdot d_{0}^{2} \cdot h_{0}}{4}-$ tested roll volume, $\mathrm{m}^{3}$.

The knowledge in the forming resistance $k_{o}$ is very important, because the deformation force depends on its value.

\section{Results and discussion}

The tests were carried out using three different steels of different chemical compositions (Table 1)

\begin{tabular}{|c|c|c|c|c|c|c|}
\hline Element & $\begin{array}{c}\text { Steel 1: } \\
\text { ČSN } 41 \text { 1373 }\end{array}$ & $\begin{array}{l}\text { Used } \\
\text { steel }\end{array}$ & $\begin{array}{c}\text { Steel 2: } \\
\text { ČSN } 41 \text { 5142 }\end{array}$ & $\begin{array}{l}\text { Used } \\
\text { steel }\end{array}$ & $\begin{array}{c}\text { Steel 3: } \\
\text { ČSN } 41 \text { 9810 }\end{array}$ & $\begin{array}{l}\text { Used } \\
\text { steel }\end{array}$ \\
\hline $\mathrm{C}$ & $\max .0 .17$ & 0.09 & $0.38-0.45$ & 0.41 & $1.20-1.35$ & 1.31 \\
\hline $\mathrm{Mn}$ & $\mathrm{x}$ & $\mathrm{x}$ & $0.50-0-80$ & 0.7 & Max. 0.45 & 0.22 \\
\hline $\mathrm{Si}$ & $\mathrm{x}$ & $\mathrm{x}$ & $0.17-0.37$ & 0.28 & $\max .0 .45$ & 0.19 \\
\hline $\mathrm{Cr}$ & $\mathrm{x}$ & $\mathrm{x}$ & $0.90-1.20$ & 0.94 & $4.00-4.80$ & 4.58 \\
\hline $\mathrm{W}$ & $\mathrm{x}$ & $\mathrm{x}$ & $\mathrm{x}$ & $\mathrm{x}$ & $10.00-12.00$ & 10.87 \\
\hline Mo & $\mathrm{x}$ & $\mathrm{x}$ & $0.15-0.30$ & 0.2 & $\max .0 .50$ & 0.17 \\
\hline $\mathrm{V}$ & $\mathrm{x}$ & $\mathrm{x}$ & $\mathrm{x}$ & $\mathrm{x}$ & $3.60-4.50$ & 3.98 \\
\hline $\mathrm{P}$ & $\max .0 .045$ & 0.014 & $\max .0 .035$ & 0.019 & $\max .0 .035$ & 0.021 \\
\hline $\mathrm{S}$ & $\max .0 .045$ & 0.018 & $\max .0 .035$ & 0.012 & $\max .0 .035$ & 0.015 \\
\hline
\end{tabular}
and mechanical values.

Chemical composition of steels according to standards [17-19] and chemical composition of used steels (weight \%) 
Steel 1 [17] is unalloyed constructional fine-grained low carbon steel 11373 according to the ČSN 411373 (corresponds, e.g., to steels S235JRG1 or 1.0036 or USt 37-2). Steel 2 [18] is chromemolybdenum steel 15142 according to the ČSN 415142 (corresponds, e.g., to steels 42CrMo4 or 1.7225 or CrMo140 FE). Steel 3 [19] is high speed steel 19810 according to the ČSN 419810 (corresponds, e.g., to steels 1.3302 or R9F5).

The results are presented in Table 2 and Fig. 3.

Table 2

Test results

\begin{tabular}{|c|c|c|c|}
\hline \multirow{2}{*}{$\begin{array}{c}\text { Forming } \\
\text { temperature, }\end{array}{ }^{\mathbf{o}} \mathbf{C}$} & \multicolumn{3}{|c|}{ Forming resistance, MPa } \\
\cline { 2 - 4 } & Steel 1 & Steel 2 & Steel 3 \\
\hline 20 & $1344 \pm 99$ & $7522 \pm 8$ & $21188 \pm 91$ \\
\hline 400 & $964 \pm 32$ & $3239 \pm 62$ & $8467 \pm 38$ \\
\hline 700 & $636 \pm 26$ & $1531 \pm 76$ & $3784 \pm 76$ \\
\hline 1000 & $286 \pm 18$ & $380 \pm 3$ & $907 \pm 44$ \\
\hline
\end{tabular}

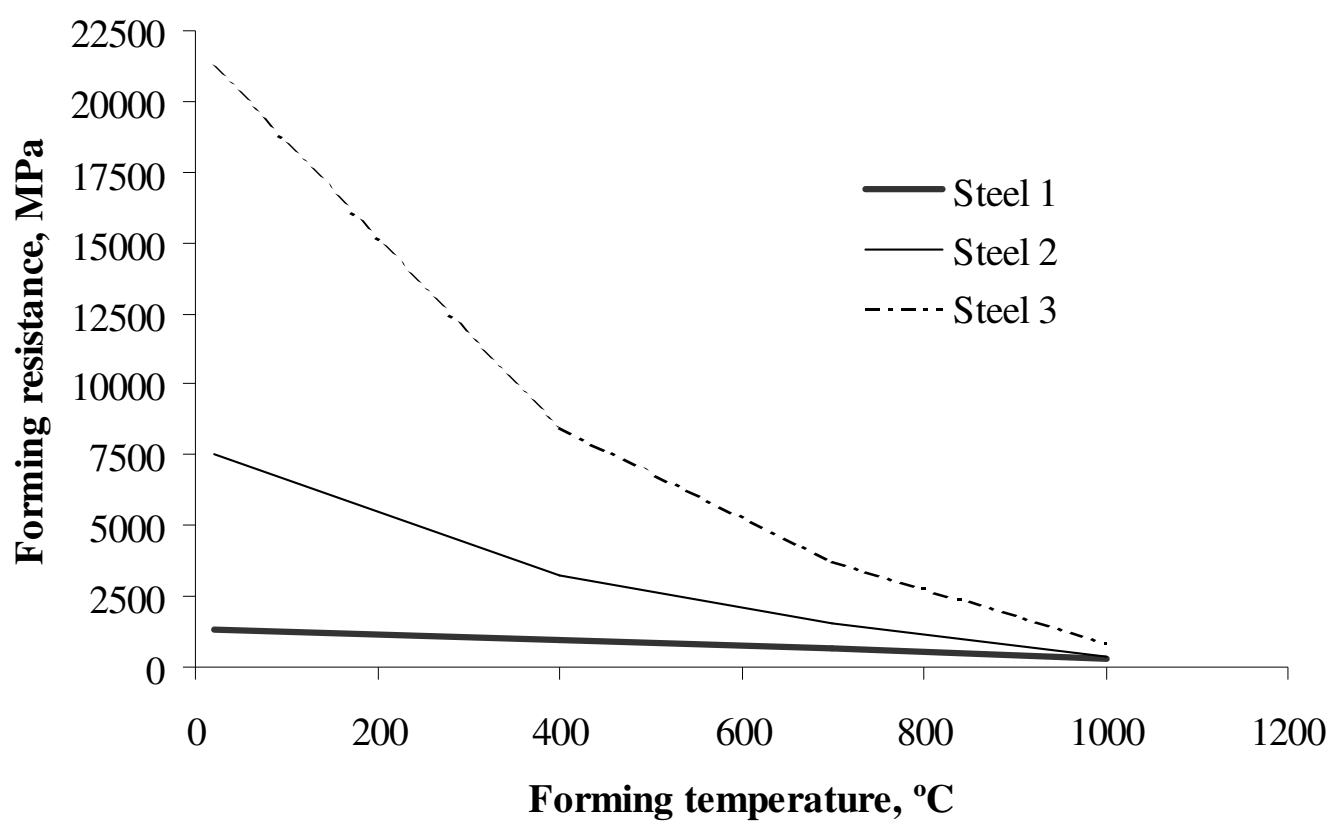

Fig. 3. Test results (standard deviation is demonstrated by the line segments)

From the carried out tests it is evident that at the temperature of $20^{\circ} \mathrm{C}$ the steels were of very different forming resistance values - from about $1340 \mathrm{MPa}$ to about $21200 \mathrm{MPa}$. With increasing the forming temperature the forming resistance of all three steels decreases. At the highest test temperature of $1000{ }^{\circ} \mathrm{C}$ the forming resistance values are from about 290 to about $900 \mathrm{MPa}$.

The aim of the above described experiments was to verify the published literature sources and to find whether it is possible to prepare on this basis the laboratory practice, which can be carried out by students in a matter of 90 minutes. It was determined that by us the measured values are in line with the published data. Further it was determined that at the observance of the above mentioned procedure the laboratory practice completion is in our department conditions real. Therefore, the practice of the title "Forming resistance experimental determination using the forging test" was prepared and tested at teaching.

\section{Conclusions}

The paper contains the results of the forming resistance experimental determination using the forging test. The aim was to verify the published literature sources and to get data for the laboratory practice preparation for the students of our faculty. 
In the experiments the test samples from three different steels were included. The tests were carried out at different forming temperatures, namely $20^{\circ} \mathrm{C}, 400{ }^{\circ} \mathrm{C}, 700{ }^{\circ} \mathrm{C}$ and $1000{ }^{\circ} \mathrm{C}$ using the fall hammer own design, made in the workshops at our department.

It is possible to state that our tests were in line with the results published by other authors. Using the obtained results the new laboratory practice was prepared and successfully tested for the students of the subjects "Manufacturing technology I" and "Basic of Manufacturing Technology".

\section{References}

1. Nováková A., Brožek M. Evaluation of helical springs. $9^{\text {th }}$ International Scientific Conference "Engineering for Rural Development". May 27-28, 2010, Jelgava, Latvia, pp. 242-245.

2. Brožek, M., Nováková, A., Mikuš, R. Study of wear resistance of hard facings using welding powders on the NiCrBSi basis. $4^{\text {th }}$ International Conference "Trends in Agricultural Engineering". September 7-10, 2010. Prague, Czech Republic, pp. 115-118.

3. Brožek, M. Soldering sheets using soft solders. Acta Universitatis Agriculturae et Silviculturae Mendelianae Brunensis. Vol. 61(6), 2013, pp. 1597-1604.

4. Nováková A., Brožek M. Bonding of non-metallic materials using thermoplastic adhesives. $8^{\text {th }}$ International Scientific Conference "Engineering for Rural Development". May 28-29, 2009, Jelgava, Latvia, pp. 261-264.

5. Brožek, M. Technical-economical evaluation of plywood bonding. $5^{\text {th }}$ International Conference "Trends in Agricultural Engineering". September 3-6, 2013. Prague, Czech Republic, pp. 100105.

6. Pavelka, R., Brožek, M. Truck cabin corrosion resistance observation in artificial atmosphere. $13^{\text {th }}$ International Scientific Conference "Engineering for Rural Development". May 29-30, 2014, Jelgava, Latvia, pp. 174-180.

7. Brožek, M. Cutting Conditions Optimization When Turning Overlays. Journal of Materials Processing Technology. vol. 168(3), 2005, pp. 488-495.

8. Brožek, M. Turning of Overlays Using Tools Produced by the Company Walter. Strojniški Vestnik - Journal of Mechanical Engineering, vol. 48(9), 2002, pp. 501-515.

9. Nováková, A., Brožek, M. Evaluation of teaching the subject "Basic Engineering Technologies". $10^{\text {th }}$ International Scientific Conference "Engineering for Rural Development". May 26-27, 2011, Jelgava, Latvia, pp. 542-547.

10. Blaščík, F. et al. Technológia tvárnenia, zlievárenstva a zvárania (Technology of forming, founding and welding). Bratislava: ALFA, 1988. 832 p. (In Czech).

11. Brožek, M. Strojírenská technologie I, návody ke cvičením (Manufacturing technology I, instruction for practice). Praha: ČZU, 2008. 80 p. (In Czech).

12. ČSN 226001 standard "Názvosloví technologie tváření kovů (Glossary of terms used in metal forming technology)". (In Czech).

13. Theis, H. E. Handbook of metalforming processes. New York: Dekker, 1999. 655 p.

14. Kliber, J. Základy tváŕení kovů (Basic of metal forming). $3^{\text {rd }}$ Ed., Ostrava: VŠB-TU, 2008. 267 p. (In Czech).

15. Čermák, J. Určení přetvárného odporu na padostroji (Forming resistance determination using the falling test). Praha: ČVUT, 2009. 3 p.

16. Technologie objemového tváŕení - kování (Volumetric forming technology - forging). [online] [14.01.2017] Available at: http://www.ksp.tul.cz/cz/kpt/obsah/vyuka/skripta_tkp/sekce/03.htm.

17. ČSN 411373 standard "Ocel 11373 (Steel 11 373)".

18. ČSN 415142 standard "Ocel 15142 Cr-Mo (Cr-Mo Steel 15 142)".

19. ČSN 419810 standard "Ocel 19810 rychlořezná (High Speed Steel 19 810)".

20. Česká zemědělská univerzita v Praze. Padací buchar (Fall hammer). Milan Brožek. Česká republika. Průmyslový vzor 35718 (Industrial design 35718). [online] [14.01.2017] Available at: https://isdv.upv.cz/webapp/WEBAPP.vzs.det?xprim $=1901986 \& l a n=c s \& s \_m a j s=\% C 4 \% 8 D e s k \% C$ 3\%A1\%20zem\%C4\%9Bd\%C4\%9B1sk\%C3\%A1\%20univerzita\&s_puvo=Milan\%20Bro\%C5\%B Eek\&s_naze= 